Forum Kritika: Performance and Domination

\title{
HEROES WITH THEIR HANDS IN THE AIR: MEMORY AND COMMEMORATION IN THE CONTEMPORARY DOCUMENTARY THEATER
}

\author{
Sheila McCormick \\ Edge Hill University, UK \\ Sheila.mccormick@edgehill.ac.uk
}

\begin{abstract}
Documentary theatre has the capacity to confront and challenge its audience; however, there are occasions when examples from the genre avoid confrontation. These examples might not promote ideas consistent with the political status quo; neither, however, do they challenge it. This paper examines the ability of documentary theatre to move between two extremes: of challenging dominant power structures, or reinforcing the political or social status quo. It contrasts two documentary theatre performances that both took place on the fringes of mainstream theatre production, and which both explore the same social event: Bloody Sunday and the Saville Inquiry. In doing so, the article asks if Norton-Taylor's Bloody Sunday: Scenes from the Saville Inquiry and Brady's Heroes with Their Hands in the Air provide examples of documentary theatre as a forum for critical engagement or as a means to elicit unchallenging emotional responses from an audience.
\end{abstract}

\section{Keywords}

Bloody Sunday, Northern Ireland, theatre of testimony, memory, commemoration

\begin{abstract}
About the Author
Sheila McCormick is a lecturer in drama at Edge Hill University. Having originally trained as an actor at the Arden School of Theatre, Sheila went on to study at Trinity College Dublin and the National University of Ireland, Galway, where she completed her PhD in documentary theatre. Sheila's current research interests stem from a former career as a qualified general nurse and are positioned within the strands of performance and health and medical humanities.
\end{abstract}


TESTIMONY AND WITNESS have increased in importance as former certainties-faith in facts [...] - have drained away from 'post-documentary' cultures in [mediatized] societies. Documents have become vulnerable to postmodern doubt.... But the witness's claim to authenticity can still warrant a credible perspective (Paget 235-6).

This paper examines performances of Fintan Brady's theatre of testimony play Heroes with their Hands in the Air produced in Derry, during the Bloody Sunday memorial weekends, in 2007 and 2012. It asks if identity is codified or fixed through acts of commemoration, such as the performance of Heroes, and examines potential outcomes if that is the case. By exploring the physical and cultural space the play claims, this paper also explores the wider implications of Heroes (other than its immediate consequences for those present on Bloody Sunday) as a performative re-enactment of memory.

Brian Conway suggests that "the strong textual tilt that seems to dominate social science scholarship [...] removes attention from [...] embodied means of remembering the past" ("Moving through Time" 104). He continues by arguing that the foregrounding of texts "comes at the expense of bodies and can be mapped on to a wider shift from oral to print culture" (104). Embodied social memory does exist however and is performed via a number of social practices that include memorial ceremonies. One such social practice is the annual Bloody Sunday memorial weekend ${ }^{1}$, an event that commemorates the thirteen victims shot and killed by the British Army on the streets of the Bogside, a Catholic housing ghetto, outside the 17 th century walls of the city of Derry on 30 January 1972.

The formal ceremonies that occur during the Bloody Sunday memorial weekend allow a performative re-enactment of history, with the annual reproduction constructing and confirming the participants' communal memory. This paper examines the assertion of an identity that is physically and culturally performed through acts of commemoration and memory.

\section{The Troubles and Bloody Sunday}

The Northern Ireland Troubles span decades and include issues such as sectarianism and civil inequality. It is important to note, however, that in the period immediately prior to Bloody Sunday 30 January 1972, it was the matter of civil rights for the marginalized Catholic community in the North that was the focus of the conflict (Hancock, "Northern Ireland").

On 30 January 1972, British soldiers fired upon a civil rights march of 20,000 protesters, killing thirteen men (with one other man dying from his injuries four months later) and injuring fifteen. Known as Bloody Sunday, the events of that day in Derry are viewed by many as the catalyst for the ensuing decades of violence in 
Northern Ireland, the Republic of Ireland and Britain. Indeed, Graham Dawson notes:

Bloody Sunday occupies a pivotal position in the unfolding history of the Troubles. Throughout the war it was situated at the very center of the politics of memory, and the repercussions of its unresolved [...past] - at once political, cultural and psychic - have continued to reverberate more than three decades later, within the ongoing conflict over the vision and direction of the peace process. (Making Peace with the Past 89)

Though organizers of the march expected hostilities on the day, no individual could have predicted the extent of the violence inflicted upon unarmed civilians. Similarly, no one could have predicted the importance of that day and its lasting effect on Northern Ireland ${ }^{2}$, as Bernadette McAliskey argued in her testimony at the Saville Inquiry in 2001:

For thirty years, as a consequence of Bloody Sunday, my policy was death is part of the equation. The British Army declared war on the people seeking justice in this country on that day. Three thousand and more coffins followed and years of imprisonment and torture and pain. It is highly arguable that without Bloody Sunday where we are today we would not have been in $1972^{3}$. (qtd. in Norton-Taylor 31)

Brian Conway notes that within "memory literature increasing attention is given to memory politics and to the ways in which the past can be mobilized to underwrite group identity as well as a form of resistance and negotiation" (2008 2). Thus the performance of memory works to solidify group identity. With this in mind, by examining a number of assumed truths regarding the Northern Ireland conflict we are able to analyze the performance of memory in relation to the production of commemorative practices performed during the Bloody Sunday memorial weekend, including the performance of Heroes.

In 1971, the British government implemented an internment policy, which allowed the Royal Ulster Constabulary, the then police force in Northern Ireland, to hold individuals without charge for unlimited periods. This infringement of civil liberty fueled the growing unrest in Northern Ireland. The policy was a misguided attempt by the British government to quell the growing civil dissatisfaction and, according to Patrick Hays and Jim Campbell, in its first year saw the internment of "2,400 mostly Catholic, Nationalist men" (15).

Following an apparently "successful" model used in Northern Ireland between 1956 and 1960, the government pursued its policy of internment with enthusiasm, a decision that proved ill-advised in the more polarized society of 1970 Northern Ireland. The unjust, and strategically unsound, model of internment could not help 
but raise the civil consciousness of the Northern Ireland community, a community that soon began to command both national and international attention. As Hayes and Campbell note, the events in Northern Ireland coincided with "a time when the voice of civil rights movements had become heard throughout the industrial world" (15). The British government's choice to support an undemocratic internment policy not only encouraged an increase in civil disobedience but also in community support for the Provisional IRA.

Further civil liberty infringements, including the banning of non-violent civil rights marches and the implementation of curfews, fueled the growing support by the Nationalist community for paramilitary organizations and a further disintegration of relations between the Catholic community and the British Army. Originally viewed by the Catholic community as a peacekeeping force sent to restore order, the British army soon became known as having an even heavier hand than the Royal Ulster Constabulary. The pressurized relations between the civilian community and the British Army came to a head on the 30 January 1972, when the British army fired upon its own civilians during a non-violent civil rights march on the streets of Derry.

\section{Trauma and Identity}

For thirty years artists, filmmakers and playwrights have attempted to understand the events of Bloody Sunday and their devastating effects. Brian Friel's play The Freedom of the City was written in the immediate aftermath of the atrocity. Later, films such as Sunday (Jimmy McGovern, 2002) and Bloody Sunday (Paul Greengrass, 2002) were produced to mark the thirty-year anniversary of the atrocity. Both films, as well as Friel's play, Frank McGuinness's Carthaginians (1988), Dave Duggan's Scenes from an Inquiry (2002), Lawrence McClenaghan's Along the Aul Road (2004) and Norton Taylor's Bloody Sunday: Scenes From the Saville Inquiry (2005), to name but a few, interrogate the events of the day. Along with commemorative devices such as murals and statues, these cultural expressions exemplify the need felt by artists in Northern Ireland to make some sense of the events of Bloody Sunday.

A particular kind of political necessity repeatedly challenges the authenticity and validity of information in the public domain, out of which emerges the figure of the witness.

Theatre of testimony (a phrase first coined by American theater maker Emily Mann) validates the credibility of the witness. It does so, first in the body providing the information (the one recounting the corporeal experience of witnessing the events described), and secondly, in the position of the audience member whose corporeal presence allows the receiving and witnessing of information to occur communally with fellow audience members. 
Adapted from Eamonn McCann's 2006 book The Bloody Sunday Inquiry-The Families Speak Out (2006), the theater of testimony play Heroes with Their Hands in the Air (Heroes) was first performed during the annual Bloody Sunday memorial weekend in 2007. It featured performances by seven actors from Derry, some of whom had been at the civil rights march in 1972 or were directly involved with the families of those killed that day, a fact which Carole-Ann Upton argues enabled them to achieve "a high degree of ownership of the piece amongst the community" (181-182).

In McCann's words, the production includes:

reflections by members of the Bloody Sunday families on Bloody Sunday itself but, more particularly, on their experience of attending the Saville Inquiry and the effect that has on them and the extent to which they see the truth about Bloody Sunday emerge in the context of those legal proceedings. (Browne, "Interview with cast of Heroes with Their Hands in the Air")

The play consists of several monologues interwoven together. Characters appear on stage, introducing themselves and their family member killed on Bloody Sunday. Importantly, they also locate the geographical position of that family member when they were shot, highlighting the importance of place to the performance of memory. As the play progresses, the characters explore and express, through direct address, their experiences of Bloody Sunday, the Widgery Report and the Saville Inquiry with the seven actors inhabiting the stage individually or in ensemble, dramatizing the sense that the traumatic effect of Bloody Sunday is both individual and communal.

In a way that acknowledges both the complexity of documentary evidence involved in so-called "truth" recovery and the importance of location to the identity of community and self, the set of Heroes remains covered throughout with a map of the Bogside. This is an important signifier when set against the manner in which Lord Saville allowed soldiers to give evidence at the inquiry. Citing concerns regarding possible paramilitary retaliation, Saville moved the inquiry from Derry to London and allowed soldiers to give evidence anonymously. Focusing on the families' experiences of Bloody Sunday and the two subsequent inquiries, Heroes challenges these special arrangements and their effect of further marginalizing the victims of Bloody Sunday. Kevin McDaid was seventeen on Bloody Sunday, three years younger than his brother, Michael, who was shot and killed at the Rossville Street Barricade. He testifies to his sense of disenfranchisement, stating:

Listen. The Inquiry was never really in our hands. That's the way it went. And it was removed from us completely when it moved over to England. Not just because of the physical distance. But because it only happened that way to accommodate the soldiers. They were in their own place. Their names weren't 
given. Some of them we weren't allowed to see, even if you'd been there. (qtd. in Brady 20)

Performances, such as those presented in Heroes, can potentially mark traumatic historic events through representation. If this is the case, then one must question the outcome of such marking. Is it possible that such marking might inhibit further exploration of those events? Does the potential exist for representations of traumatic events to divest those events of their impact and thus risk an audience becoming desensitized to a traumatic event through over-familiarization? These questions become particularly relevant when we consider the decision to revive Heroes for the Bloody Sunday memorial weekend in 2012, eighteen months after the publication of Lord Saville's findings.

At its premiere in 2007, Heroes was accompanied and contextualized by other performative devices, produced publicly to assert a truth regarding the events of Bloody Sunday. A public debate, the reclamation of the traumatic space by the Bloody Sunday Museum, the march to the Bloody Sunday memorial, and, finally, the performance of Heroes inside the walls of Derry at the Derry Playhouse all worked together, authenticating each other and lending authority to the version of truth presented. This original version encapsulated the social memory of the Bogside residents affected by the events of 30 January 1972.

One of those performative devices, a public forum entitled "Making Peace with the Past" took place in Pilot's Row, Rossville Street, a community center situated in the heart of the Bogside. Here the cross-community, Healing through Remembering Organisation, gave its executive summary on options for communal reconciliation and rehabilitation in Northern Ireland. During the forum, the terminology used to describe those affected by the Troubles was publicly discussed with a family member of one of those killed on Bloody Sunday suggesting that the notion of victimhood removes autonomy ${ }^{4}$. In her opinion, survivor terminology should be used to describe her and others' experience of violence enacted upon them without provocation. The conversation continued into a heated and obviously personalized debate, suggesting an intrinsic link between these definitions and personal identity.

The community center where the forum took place sits directly across from the old Rossville flats where much of the violence took place on Bloody Sunday; beside it sits the Bloody Sunday memorial and within walking distance the Free Derry monument. Also, within yards, is the Bloody Sunday Museum, newly erected in 2007 and officially opened that same memorial weekend. Displaying personal and communal artefacts, the museum was set up and funded by the Bloody Sunday Trust ${ }^{5}$. Providing its own funding, the Bloody Sunday Museum chooses communal rather than official representation. It reclaims past events and educates the public, producing meaning that is generated from within the community rather than imposed from the outside by the state. Each of these devices suggests an intention 
within the community of the Bogside to dissent from the official explanation of Bloody Sunday and define its own identity.

Identity and history are difficult to separate. Because of this, as Wendy Brown argues,

"The past cannot be redeemed unless the identity ceases to be invested in it, and it cannot cease to be invested in it without giving up its identity as such, thus giving up the economy of avenging and at the same time perpetuating its hurt" (73). Trauma, with its many physical, psychological, and geographical attachments, runs the risk of de-historicizing those who have suffered and removing any past other than the defining spectacle of aggression enacted upon them.

The re-witnessing of events during Heroes encourages the audience to recall their own memories, the culmination of both leading to a higher degree of involvement in the subject matter. Although the publication of the Saville Inquiry on 15 June 2010 clears the majority of victims of Bloody Sunday of any wrongdoing, earlier commemorative devices were staged to represent that innocence. In a way that suggests a form of trauma tourism, in 2007, visitors to the Bogside photographed the commemorative devices and visited the museum, while around them a community awaited the outcome of the Saville Inquiry. For the survivors of Bloody Sunday, these sites, frozen in memory, might constitute actual geographical obstacles to the development of new memories.

As Dawson notes, commemoration provides "a symbolic reclaiming and 'detoxifying' of the site of the atrocity - a contaminated space of trauma and deathby and for the local community" ("Trauma, Place" 152). In 2007, three years before the release of Justice Saville's findings, perhaps the only redress for the survivors of Bloody Sunday and their legacy of trauma was through commemoration, in activities such as those found during that memorial weekend and in the performance of Brady's Heroes, as well as the many murals positioned at the heart of the landscape where the trauma took place.

Commemoration in the theatre of testimony play Heroes depends on other performative texts to stabilize the identity it attempts to reclaim. Without punishment for the perpetrators of Bloody Sunday, perhaps the only redress for the survivors of that day and their legacy of trauma is through commemoration in acts such as Brady's Heroes. If that is true, then it leads one to question the logic behind the revival of the play by theatre company Fahy Productions during the memorial weekend of 2012 in a landscape utterly changed by the Saville Report and the subsequent apology for the atrocity by Prime Minster David Cameron on the 15 January 2010.

In a statement outlining the events of the 2012 memorial weekend, the Pat Finucane Centre for Human Rights and Social Change ${ }^{6}$ suggested, 
There is widespread belief that the events of June 15th 2010 represent a journey's end with an outcome previously considered inconceivable. The British Government have been forced to admit their terrible wrong-doing before the world. We are all in a better place because of that. This is what we have achieved together. (Pat Finucane Centre)

The statement continues,

Last January, the vast majority of families decided that the 39th Anniversary would be the last march [...] The 4oth Anniversary will allow us all time to reflect on the entirety of the journey we have taken. (Pat Finucane Centre)

While the theme of the 4oth Anniversary appears to be one of reflection, the central issue of Gerald Donaghey's innocence remained crucial and features significantly in the program of events. Unlike all of the other victims exonerated of any terrorist activity on Bloody Sunday, Saville found that teenager Donaghey was "probably" carrying nail bombs, an outcome the families of the Bloody Sunday victims refuse to accept.

Audiences' responses to the 2012 production of Heroes suggest the play still resonates, with one audience member claiming the play took him back to the Bogside in 1972 and the Guildhall (where the Saville Inquiry was held in Derry) in June 2011: "I really could feel the families' pain and sorrow and the emotional rollercoaster through this play" (Audience Feedback Sheets, Brady Productions). Another suggests, "to give closure and healing to us Derry people we need the like of plays and discussions so we can move on" (Audience Feedback Sheets, Brady Productions).

Much like the production in 2007, Conaghan's 2012 production of Heroes includes testimonies from those most affected by the events of Bloody Sunday, the families of the victims. This production differs however in that it is extended to include reactions by the family members to the findings of the Saville Inquiry. Thus, the choice to re-examine the play in 2012 can be considered as a means to, in Conaghan's words "interrogate the issues of Public Inquiries," because, as the playwright and theatre director continues, as an artist and a human rights activist he feels "theatre can bring these questions to the forefront and maybe help lobby local governments" (15 Mar. 2013, email). For Conaghan, this became the focus for the production of Heroes in 2012, which unlike the production of 2007 also took place outside Derry in Cultúrlann. Situated in Belfast, Cultúrlann, an Irish language and culture venue, states its mission has always been based in a "a nonpolitical, independent mind-set that values our language and culture as part of the common heritage of all the people" (Cultúrlann).

Perhaps the significance of the play remains and is compounded by its relation to another documentary theatre play also produced during the 2012 memorial 
weekend, The Saville Report and Gerald Donaghey-Unfinished Business. As the 2012 director of Heroes continues:

We are currently working with the Donaghey family on the issues on young Gerard Donaghey, who has still not been fully cleared of his innocence (the report still claims that he probably had nail bombs on his person the day of Bloody Sunday). Whenever we started our thoughts on producing Heroes, I wanted to firstly produce a piece of theatre for the 4oth anniversary of Bloody Sunday, and to make the public aware that they are still pushing for prosecutions. Secondly, to use this verbatim play as a supplement or manual for other families who are campaigning for a public inquiry (Conaghan, 15 Mar. 2013, email).

During The Saville Report and Gerald Donaghey-Unfinished Business, individuals presented civilian, British Army and RUC evidence heard at the Saville Inquiry while Eamonn McCann narrated because, as the Pat Finucane Centre continues, "this remains unfinished business not only for the Donaghey family but for the wider community" (PFC).

Just like the Saville Inquiry, both of Heroes and The Saville Report and Gerald Donaghey have the capacity to resonate long after their initial productions precisely because of Lord Saville's findings. As an actor in Heroes notes, "Part of bringing to closure all of the hurts of the Troubles is that the truth needs to be told to the families of those who lost loved ones... in whatever incident that took place" (Browne, "Interview with cast of Heroes with Their Hands in the Air"). The publication of the Saville Inquiry has led to an acknowledgment of innocence for some but not all victims of Bloody Sunday. This acknowledgment is necessary, as the claim that the victims were in some way culpable produces further trauma felt both by the families of the victims and also by the community to which they belonged. Thus, rather than observe a past trauma in isolation, Heroes exposes the continued effect of traumatic events on individuals and their community long after the event itself.

\section{Heroes with Their Hands In The Air: Commemoration and Memory}

Herbert Lindenberger notes the danger with commemorative practices is that through them "the historical past becomes a kind of closed book, one which is to be re-enacted much as a religious ritual re-enacts some hallowed event" (24). However, theatrical representation can successfully refer to reality when we, the audience, remain aware of the truthful foundations that lead to the production of documentary theatre and the mediation that has occurred prior to its arrival on stage. 
In relation to commemoration, Aileen Blaney argues that "since the instigation of the Northern Ireland peace process, issues relating to the commemoration of the political conflict have moved to centre stage in media, political, cultural and academic discourses" (113).

Indeed, in 2002 (four years after the signing of the Good Friday Agreement) two films depicting the events of the 30 January 1972 were produced on the thirtieth anniversary of Bloody Sunday. Paul Greengrass' film Bloody Sunday aired on Granada television, was a collaborative enterprise between the filmmaker, members of the Derry community (who acted as consultants and cast members), and professional soldiers. Jimmy McGovern's Sunday was also shown on British television with Channel 4 airing the production following an intensive research period conducted with the help of the communities involved.

In a similar way to theatrical representations of Bloody Sunday, these filmic representations appear to attempt to work through trauma and memory mobilizing what Blaney describes as "iconic imagery in a dramatic narrative populated by proximate characters" in that they "invite informed viewers to revisit, and uninformed viewers to witness, Bloody Sunday from the 'past' " (117). Resembling Heroes, filmic representations re-externalize the violence of Bloody Sunday using the testimonies of eyewitnesses to preserve archival imagery.

In Blaney's opinion, Greengrass' docudrama film attempts to “'tid[y] up' the matrix of political and historical forces circulating on the day by privileging certain narrative moments and its cast of sympathetic characters," but that does not "automatically annul its analytical capacities" (119). If that is true of docudrama, what of theatre of testimony in which the actual words of traumatized individuals are spoken? Do its claims to veracity and authenticity "annul its analytical capacities" (Blaney 119)?

Attilio Favorini argues that those who remember "often encounter the past in a manner that is inescapably diachronic and relational, connecting past to present and bridging temporal distance via the stepping stones of a lived life" (152). Unavoidably linked to the passage of time and its effect on the identity of the traumatized individual, suffering transgresses temporal distance in the psyche of those traumatized. In the case of Bloody Sunday 1972, the remembrance of trauma occurs through public and private performative, commemorative devices that rely on autobiography, reminiscence, and nostalgia. The devices influence how the community in which the trauma took place (and, indeed, the wider society) understands the events that caused the trauma.

Also important in the understanding and analysis of trauma and memory are the examination of place and the relationship of the traumatized body to the place in which the trauma took place. Deirdre Heddon argues that the particularity of any site is dependent on the specific bodies that inhabit it, and the same is true of those bodies; because identity and place are mutually constructed, they depend on each other to produce meaning. The relationship between the body and the 
space is integral to all creative practices because, as embodied subjects, space and time always constitute our presence. We are always in our bodies and our bodies are always in a space. Similarly, space is informed by the bodies that inhabit it. As bodily constituted, we are in a place and, as such, are part of it. Therefore, as a collection of bodies in any space, we mark that space with a collection of meanings and identities that are socially and historically specific.

Brady's Heroes is positioned doubly, being specific to both a particular time and place. Positioned around other events, including a wreath-laying ceremony, prayer service, and commemorative march, the timing of the production of the play (in both 2007 and 2012) further serves to authenticate its political resonance. Each of the commemorative devices provides an ideological document that further grounds the subject, and, by association, the play's importance.

Geographically and terminologically, Derry has signified a contested space from as long ago as the seventeenth century. For Irish nationalists the city remains "Derry," while for Ulster Unionists it is designated by the name "Londonderry." This in itself is symbolic of the complex relationship that exists between Derry and its inhabitants that emerges out of a contested history and a political association to the geography of the city and its walls that remains vital. As Dawson notes:

In the popular memory of Derry's Catholics, loyalist commemoration of the siege made Derry City and its Walls a symbol of Protestant domination and of their own second-class status. Overlooking the Bogside from their commanding position on the impregnable Walls, the loyalist parades exude provocation and threat, while nationalists' own smaller commemorative parades, to mark the 1916 Easter Rising, were contained in the Bogside ghetto. (Making Peace with the Past 92)

Although in the majority since 1966, Derry's Catholics have historically endured a double exclusion. Following their consolidation within Northern Ireland after 1922, as Dawson continues, the "special manipulation of gerrymandered electoral boundaries secured permanent political dominance of the Unionist electorate in a city where, by 1966, Catholics formed two-thirds of the population" (Making Peace with the Past 93). Thus, the exclusion of Catholics in Derry occurred by trapping them, geographically, in the ghetto of the Bogside and, politically, in a discriminatory political system. The Northern Ireland civil rights movement launched in 1968 was an attempt to address this inequality by means of protest and civil disobedience, such as the march on Bloody Sunday.

The performance site used to house the production of Heroes in 2007 and 2012 (the Playhouse Theatre) thus resonates as a political signifier as it places the testimonies of those affected by the massacre of Bloody Sunday firmly within the city walls of Derry. This position, within the notorious city walls, was historically withheld from the marginalized Catholic community, the community most 
affected by the events of Bloody Sunday. The play, therefore, repositions the trauma of Bloody Sunday, moving it from its original site, the marginalized position both physically and metaphorically of the Bogside, to a highly visible position within the historical realms of the once-dominant group.

Heddon suggests that we should think of autobiography as the cartography of self. Lives do actually take place; they happen somewhere and are, therefore, located. They are not only embodied as a gendered or raced subject, they are also embodied in and through the specific places they inhabit. Placing Heroes within the main arts venue of the city provided the production with a physical artefact made of bricks and mortar that further highlighted the social and political injustices from the city's past, injustices that, at one time, would have prevented such a production from occurring.

According to the Playhouse Theatre, its situation is "based on a neutral site within the city centre... a self-help, grass roots, bottom-up community development project which is [people-centered]," a claim that further compounds the importance of its geographical position (The Playhouse Theatre). In Brady's Heroes, actor, audience and ideology collide to provide an experience that is mediated on several levels. The production is housed in an area of Derry with specific connotations. The characters in the production discuss both their own memories of Bloody Sunday and the day itself as mediated through the Saville Inquiry. Finally, the audience contemporaneously experiences the performance through their own politics and their experience of the Bloody Sunday and The Troubles.

Conway suggests, "[t]he literature on collective memory is based on very strong geographical understandings of the basic co-ordinates of time and space" ("Local Conditions" 4). For this reason, analysis of the performance of trauma needs to account for both literal and abstract features of both. To understand the collective memory of trauma one must assess both the event that caused the trauma, and the way in which that trauma has been dealt with in the period since the event. Trauma, and the memory of it, must be assessed in conjunction with time and space, in relation to both past and present.

While this paper argues the performance of memory that occurs in Heroes potentially freezes in time the trauma of Bloody Sunday for its audience and the community in which it is based, it also acknowledges the advantageous position of the play to the analysis of the performance of testimony and so-called truth, and of the evocation of the past through enacted testimony. In Heroes, Brady observes the performance of memory, but in this context, the performance bears personal, rather than judicial, witness. Here the theatre of testimony form allows the communication of past trauma to occur freely and publicly, something that was not always possible during the Saville Inquiry.

If Heroes creates spaces for an analysis of the performance of testimony and truth, and of the evocation of the past through enacted testimony, it also acknowledges the fallibility of traumatic memory. Kay Duddy is the sister of seventeen-year-old 
Jamie Duddy, the first person shot and killed on Bloody Sunday. In an extract from McCann's book, she describes the experience of watching people give evidence at the Saville Inquiry:

When they spoke, you could see them back in the Bogside. You could see them crunched down, dodging bullets. You could see them running... You could see people telling their story and you could see in their eyes that they were back there. (qtd. in McCann 109)

Without corroboration, in the form of tangible evidence, legal processes can easily question, or indeed even disregard, performances of memory. Despite this, the development of the traumatic event into a narrative form and the ability to share that narrative form with others may help to produce meaning and prevent the trauma from becoming the traumatized individual's defining feature. Legal processes have the potential to make this difficult, as was seen in the families' experiences of the Saville Inquiry. However, the development of the traumatic narrative in productions such as Heroes, and the willingness on the part of the audience to bear witness to the trauma the narrative addresses, may allow the burden to be shared. This sharing of experience can then potentially act as a form of resistance, potentially assisting those who have suffered to reclaim ownership over their past and facilitating their assimilation into the present.

\section{Conclusion}

The reclamation of the past is conservative rather than oppositional if it solidifies meaning before all necessary discussion and analysis has taken place. When discussing historical trauma, reconciliation, and the Northern Ireland conflict, Brandon Hamber argues that "all societies coming out of division and conflict draw on history to arm themselves for the conflicts of the present-conflicts which for the most part are real, and are historically and materially based (1)."

In Northern Ireland, the past remains contentious and this contention inevitably affects the potential for reconciliation. Acknowledging this conundrum, Marie Smyth asks, "Can there be healing between individuals, groups or nations without those who have injured others, or whose communities have injured others, expressing both a readiness to take up the burden of guilt and regret?" (31). If the future is based on the past, can society move on without acknowledging past trauma, and can past trauma be properly acknowledged without expressions of guilt? In other words, can society move forward without open and honest debate and the recognition of past injustices?

Heroes does address an important aspect of the Saville Inquiry in terms of the experience of the Derry witnesses, and in particular, the Bloody Sunday families who were determined that their truth be told. Here the theatre of testimony form of 
documentary theatre allows the communication of past trauma to occur freely and publicly, something that was not always possible during the Inquiry. However, this form of theatre also makes it difficult to challenge or question the representation it provides, as the performance of memory is linked to the subjective experience of an event and is, therefore, difficult to dispute.

Audience members attending a documentary theatre invest their emotions and thoughts in that performance in the hope of finding some meaning. The effectiveness of this action relates to the audience member's involvement in the actual event. The re-witnessing of events during Heroes allows the exposition of the audience's own memories that surround 30 January 1972, and the events that followed. These memories, together with new ones produced through the experience of the documentary theatre, cannot help but increase the audience's involvement in the subject matter.

Acknowledging a traumatic event enables history to be rescued, as Baz Kershaw explains, "from the reign of nostalgia by the performance of the past as reclamation of its radical instability in the present" (24). The reclamation of past trauma by those who have suffered, and the representation of that trauma in the present, may have the capacity to divest the traumatic events of their mythical quality. In terms of productions such as Heroes, the use of actual experiences, although difficult to objectively criticize, allows the community an opportunity to analyze past events and specifically, to explore their effect on present situations. 


\section{Notes}

1. Since the early 1990s, The Bloody Sunday memorial weekend has been organized and run by The Bloody Sunday Weekend Committee. Originally, the memorial march held annually since 1973 was organized and run by Sinn Fein. With the involvement of the families in the late 8os and early 9os, the weekend and indeed the march itself moved from the auspices of political parties to the families of the victims of Bloody Sunday and their campaign for justice.

2. Over the course of the Troubles 3,600 individuals lost their lives. For the families of the victims of Bloody Sunday, the atrocity of the 30 January 1972 was followed by the Widgery tribunal (21 February 1972) and report (18 April 1972, now widely accepted as a whitewash), twenty six years of campaigning for a new inquiry which was finally agreed to by Tony Blair on the 29 January 1998, the opening of the Saville Inquiry on the 30 April 1998 and finally, its report, published on the 15 June 2010.

3. Josephine Bernadette Devlin McAliskey, a civil rights campaigner and socialist republican, was born in County Tyrone, Northern Ireland in 1947. She served as a Member of the UK Parliament from 1969 to 1974 and was present in Derry on the 30 January 1972.

4. I was present at the panel discussion of the Healing through Remembering, Making Peace with the Past, which took place in Pilots Row Community Centre, Rossville Street, Derry, on the 27 January 2007.

5. The Bloody Sunday Trust is a community-based education and human rights organization established in 1997. According to its mission statement it aims to encourage support for human rights and conflict transformation and an increased understanding between people both internationally and in Ireland. The Trust is also the managing body of the Museum of Free Derry.

6. The Pat Finucane Centre for Human Rights and Social Change or PFC is a nonparty political, anti-sectarian human rights group advocating a non-violent resolution of the conflict in Northern Ireland. The center is named after the human rights lawyer Pat Finucane, who successfully challenged the British Government over several important human rights cases and was murdered in front of his wife and children on 12 February 1989 by the loyalist paramilitary group, the UDA.

\section{Works Cited}

Blaney, Aileen. "Remembering Historical Trauma in Paul Greengrass's Bloody Sunday." History \& Memory 19.2 (2007): 113-138. Print.

Brown, Wendy. States of Injury: Power and Freedom in Late Modernity. Princeton: Princeton UP, 1995. Print.

Browne, Vincent. "Interview with cast of Heroes with Their Hands in the Air." Tonight with Vincent Browne. RTE Radio 1, n.d. Web. 15 July 2009. 
Conaghan, J.P. "Research into Heroes with Their Hands in the Air." Message to Sheila McCormick. 15 Mar. 2013. E-mail.

Conway, Brian. "Moving through Time and Space: Performing Bodies in Derry, Northern Ireland." Journal of Historical Sociology 20.2 (2007): 103-125. Print.

--. "Local Conditions, Global Environments and Transnational Discourses in Memory Work: The Case of Bloody Sunday (1972)." Memory Studies 1.2 (2008): 187-209. Print. Cultúrlann. "History." Cultúrlann McAdam Ó Fiaich. Web. 3 June 2013.

Dawson, Graham. Making Peace with the Past. Manchester: Manchester UP, 2011. Print.

-.-. "Trauma, Place and the Politics of Memory." Historical Workshop Journal 59 (2005): 152. Print.

Favorini, Attilio. "History, Memory and Trauma in the Documentary Plays of Emily Mann." Get Real: Documentary Theatre Past and Present. Ed. Alison Forsyth and Chris Megson. Basingstoke: Palgrave, 2009. 151-166. Print.

Hamber, Brandon, ed. Past Imperfect: Dealing with the Past in Northern Ireland and South Africa. Derry/Londonderry: INCORE/UU, 1998. 1-12. Print.

Hayes, Patrick and Campbell, Jim. Bloody Sunday: Trauma, Pain and Politics. London: Pluto, 2005. Print.

Hancock, Landon. "Northern Ireland: Troubles Brewing." CAIN Web Service. CAIN, 1998. Web. 3 Jun. 2013.

Heddon, Deirdre. Autobiography and Performance. Hampshire: Palgrave, 2008. Print.

Kershaw, Baz. The Radical in Performance: Between Brecht and Baudrillard. London: Routledge, 1999. Print.

Lindenberger, Herbert. Historical Drama: The Relation of Literature and Reality. Chicago: Chicago UP, 1975. Print.

McCann, Eamonn, ed. The Bloody Sunday Inquiry: The Families Speak Out. Dublin: Pluto, 2006. Print.

Norton-Taylor, Richard. Bloody Sunday: Scenes from the Saville Inquiry. London: Oberon, 2005. Print.

Paget, Derek. “The 'Broken Tradition' of Documentary Theatre and Its Continued Powers of Endurance." Get Real: Documentary Theatre Past and Present. Ed. Alison Forsyth and Chris Megson. Basingstoke: Palgrave, 2009. 224-238. Print.

Smyth, Marie. "Remembering in Northern Ireland: Victims, Perpetrators and Hierarchies of Pain and Responsibility." Past Imperfect: Dealing with the Past in Northern Ireland and South Africa. Ed. Brandon Hamber. Derry/Londonderry: INCORE/UU, 1998. 31-49. Print.

The Pat Finucane Centre. "Programme for Bloody Sunday Weekend 2012, 20/20 Vision - 4oth Anniversary of Bloody Sunday." The Pat Finucane Centre for Human Rights and Social Change. The Pat Finucane Center, 2013. Web. 10 Mar. 2013.

The Playhouse Theatre. "About." The Playhouse Theatre, Derry/Londonderry. The Playhouse Theatre, n.d. Web. 10 Mar. 2013.

Upton, Carole-Ann. "Northern Ireland: The Case of Bloody Sunday." Get Real: Documentary Theatre Past and Present. Ed. Alison Forsyth and Chris Megson. Basingstoke: Palgrave, 2009. 179-194. Print. 